\title{
DELOCALIZATION, GORPORATE MIGRATION, RE-INDUSTRIALIZATION AND SUSTAINABILITY - A CASE OF ROMANIAN ECONOMY
}

\author{
Cătălin POSTELNICU ${ }^{a}$, Dan-Cristian DABIJA ${ }^{\mathrm{b}, *}$ \\ a),b) Babeş-Bolyai University, Faculty of Economics and Business Administration, \\ Cluj-Napoca, Romania
}

Please cite this article as:

Article History:

Postelnicu, C. and Dabija, D.C., 2017. Delocalization, Received: 8 December 2016 Corporate Migration, Re-Industrialization and Sustainability - A Case of Romanian Economy. Review Accepted: 18 March 2017 of Economic Studies and Research Virgil Madgearu, 10(1), pp.77-108.

doi: 10.24193/RVM.2017.10.06.

Abstract: Delocalization has risen in the last years, in volume and value. This has spurred an interest for the phenomenon, particularly for what is usually called offshoring. The authors focus on Romania, an increasingly important market for multinationals that strive for economies of scale, reduce costs by employing highly qualified workforce with considerable experience and ensure the sustainable development of their businesses. Romania is an important market for industry delocalization in the clothing and footwear industry, offering real competitive advantages to companies. Delocalization can have a major impact on the reshaping of the domestic market and the chain of value-adding activities.

Key words: delocalization; Corporate Migration; Re-Industrialization; Romania; privatization; multinational corporations; internationalization

JEL Classification: F23; F15; F21; F63

(C) 2017 Alma Mater Publishing House. All rights reserved.

* Corresponding author.E-mail address: cristian.dabija@econ.ubbcluj.ro. 


\section{References}

1. Arndt, S.W., 1997. Globalization and the Open Economy, The North American Journal of Economics and Finance, 8(1), pp.71-79. https://doi.org/10.1016/s1062-9408(97)90020-6.

2. Barthelemy, J., 2007. Strategies d'externalisation. Troiseme Edition, Paris: Dunod.

3. Beck, U., 2009. World at Risk. Cambridge, UK: Policy Press.

4. Bhagwati, J., Panagariya, A. and Srinivasan, T.N., 2004. The Muddles over Outsourcing. Journal of Economic Perspectives, 18(4), pp.93114. https://doi.org/10.1257/0895330042632753.

5. Bolisani, E. and Scarso, E., 1996. International Manufacturing Strategies: Experiences from the Clothing Industry. International Journal of Operations \& Production Management, 16(11), pp.71-84. https://doi.org/10.1108/01443579610131465.

6. Breen, M. and Doyle, D., 2013. The Determinants of Privatization: A Comparative Analysis of Developing Countries. Journal of Comparative Policy Analysis: Research and Practice, 15(1), pp.120. https://doi.org/10.1080/13876988.2013.741439.

7. Bruinsma, F., Gorter, C. and Nijkamp, P., 1998. Nomadic Firms in a Globalizing Economy: A Comparative Study. In: $38^{\text {th }}$ Congress of the European Regional Science Association, August 28th September 1st, 1998, Vienna, Austria, viewed 5 June 2016: http:// papers.tinbergen.nl/98120.pdf.

8. Business24.ro, 2014. Industria auto, motorul creșterii economice în Europa Centrală şi de Est. viewed 5 June 2016: http://www. business24.ro/auto/piata-auto/industria-auto-motorul-cresteriieconomice-in-europa-centrala-si-de-est-1548295.

9. Cheben, J., Lancaric, D., Savov, R., Toth, M. and Tluchor, J., 2015. Towards Sustainable Marketing: Strategy in Slovak Companies. Amfiteatru Economic, 17(40), pp.855-871.

10. Co, H.C., David, I., Feng, P. and Patuwo, E., 2012. A ContinuosReview Model for Dual Intercontinental and Domestic Outsourcing. International Journal of Production Research, 50(19), pp.54605473. https://doi.org/10.1080/00207543.2011.638941.

11. Dabija, D.C., Pop, N.A. and Postelnicu, C., 2016. Ethics of the Garment Retail within the Context of Globalization and Sustainable Development. Industria Textila, 67(4), pp.270-279. 
12. Deardorff, A.W., 2001. Fragmentation in Simple Trade Models. North American Journal of Economics and Finance, 12(2), pp.121137. https://doi.org/10.1016/s1062-9408(01)00043-2.

13. Drumetz, F., 2004. La delocalisation. Bulletin de la Banque de France, 132, pp.27-42.

14. Dunning, J.H., Lundan, S.M. (2008), Multinational Enterprises and the Global Economy, $2^{\text {nd }}$ Edition, Cheltenham, UK: Edward Elgar Publishing Limited.

15. Earle, J. and Săpătoiu, D., 1994. Incentive Contracts, Corporate Governance and Privatization Fund in Romania. Atlantic Economic Journal, 22(2), pp.61-79. https://doi.org/10.1007/bfo2310195.

16. Egger, H. and Egger, P., 2005. Labour Market Effects of Outsourcing under Industrial Interdependence. International Review of Economics \& Finance, 14(3), pp.349-363. https://doi.org/10.1016/j. iref.2004.12.006.

17. Egresi, I., 2007. Foreign Direct Investment in a Recent Entrant to the EU: The Case of the Automotive Industry in Romania. Eurasian Geography and Economics, 48(6), pp.748-764. https://doi. org/10.2747/1539-7216.48.6.748.

18. El Mouhoub, M., 2013. Mondialisation et delocalisation des entreprises. Paris: Editeur Decouverte.

19. Eriksson, P.E., Dickinson, M. and Khalfan, M.M.A., 2007. The influence of partnering and procurement on subcontractor involvement and innovation. Facilities, 25(5/6), pp.203-214. https://doi.org/10.1108/02632770710742174.

20. Ethier, W., 1987. Dumping. The New Palgrave Dictionary of Economics. London: The MacMillan Press Limited.

21. Euractiv, 2012. Brussels to push for EU-wide minimum wage. viewed 5 June 2016: http://www.euractiv.com/section/social-europe-jobs/ news/brussels-to-push-for-eu-wide-minimum-wage.

22. Euratex, 2013. The European Apparel and Textile Confederation. The EU-28 Textile and Clothing Industry in the Year 2013, Confederation of European Business (BUSINESSEUROPE) and the Alliance for a Competitive European Industry (ACEI), viewed 25 June 2016: http://euratex.eu/library/statistics/key-data/key-datadetails/?tx_ttnews\%5Btt_news\%5D=4285\&cHash=08ob12174fofe 9ceb5bf368f4fcb9036.

23. Euratex, 2015. The European Apparel and Textile Confederation. The EU-28 Textile and Clothing Industry in the Year 2015, 
Postelnicu, Dabija, Delocalization, Corporate Migration...

Confederation of European Business (BUSINESSEUROPE) and the Alliance for a Competitive European Industry (ACEI), viewed 25 June 2016: http://euratex.eu/library/statistics/key-data/key-datadetails/?tx_ttnews\%5Btt_news\%5D=5335\&cHash=dad7deao52e6c 4e3540accdd8257bea4.

24. Eurostat, 2016a. Labour costs per hour in EUR, 2004-2015 whole economy excluding agriculture and public administration. viewed 5 June 2016: http://ec.europa.eu/eurostat/statistics-explained/index. php/File:Labour_costs_per_hour_in_EUR,_2004-2015_whole_ economy_excluding_agriculture_and_public_administration.png.

25. Eurostat, 2016b. Monthly minimum wages - bi-annual data. 29.01.2016, viewed 5 June 2016: http://appsso.eurostat.ec.europa. eu/nui/show.do.

26. EuroWORK, 2013. European Observatory of Working Life, Social Dumping. Industrial Relations Dictionary, 11.9.2013, viewed 21 June 2016: http://www.eurofound.europa.eu/observatories/eurwork/ industrial-relations-dictionary/social-dumping.

27. Farinas, J.C., Lopez, A. and Martin-Marcos, A., 2014. Assessing the Impact of Domestic Outsourcing and Offshoring on Productivity at the Firm Level, Applied Economics, 46(15), pp.1814-1828. https:// doi.org/10.1080/00036846.2014.884704.

28. Feenstra, R.C., 1998. Integration of Trade and Disintegration of Production in the Global Economy. Journal of Economic Perspectives, 12(4), pp.31-50. https://doi.org/10.1257/jep.12.4.31.

29. Feenstra, R.C. and Hanson, G.H., 1996. Globalization, Outsourcing and Wage Inequality. American Economic Review, 86(2), pp.240245. https://doi.org/10.3386/w5424.

30. Fernie, J., 2014. The Internationalization of the Retail Supply Chain. In: Fernie, J. and Sparks, L., (Eds.). Logistics and Retail Management. Emerging Issues and New Challenges in the Retail Supply Chain. $4^{\text {th }}$ Edition, London: Kogan Page, pp.59-76.

31. Franco, C., Rentocchini, F. and Marzetti, G.V., 2008. Why do Firms Invest Abroad? An Analysis of the Motives Underlying Foreign Direct Investments. European Trade Study Group ETSG, ETSG 2008 Archives, viewed 21 June 2016: http://www.etsg.org/ETSG2008/ Papers/Franco.pdf.

32. Fusea, S., 2008. Privatizarea în România. Aspecte tehnice consecințe juridice. București: Editura Universul Juridic. 
33. Gnosis, 2007. Risks and Opportunities of Delocalization. Rivista italiana di intelligence, 2, viewed 20 June 2016: http://gnosis.aisi. gov.it/gnosis/Rivista11.nsf/ServNavigE/11.

34. Gotz, Z., 2007. Determinants of International Fragmentation of Production in European Union. IWH Discussion Papers, 15, pp.228. https://doi.org/10.1007/s10663-010-9138-z.

35. Holl, A., Pardo, R. and Rama, R., 2012. Comparing Outsourcing Patterns in Domestic and FDI Manufacturing Plans: Empirical Evidence from Spain. European Planning Studies, 20(8), pp.13351357. https://doi.org/10.1080/09654313.2012.680582.

36. INS, 2013. Anuarul Statistic al României. București: Institutul Național de Statistică, viewed 21 April 2016: http://www.insse.ro/ cms/ro/content/anuarul-statistic-al-romaniei-2013.

37. INS, 2014. Anuarul Statistic al României. București: Institutul Naţional de Statistică, viewed 21 April 2016: http://www.insse.ro/ cms/files/Anuar\%20arhive/serii\%2ode\%20date/2014/Anuar\%20 statistic\%20al\%20Romaniei\%202014.pdf.

38. INSSE, 2015. Buletin statistic lunar, 11. București: Institutul Național de Statistică, viewed 21 April 2016: http://www.insse.ro/ cms/files/arhiva_buletine2015/bsl_11.pdf.

39. INSSE, (2016), Comerțul exterior al României, București: Institutul Național de Statistică, viewed 21 April 2016: http://www.insse.ro/ $\mathrm{cms} / \mathrm{ro} /$ content/comertul-exterior-al-romaniei.

40. Ioras, F., 2007. Romanian Wood Industry: Privatisation Facts. Journal of the Institute of Wood Science, 17(5), pp.239-244. https:// doi.org/10.1179/wsc.2007.17.5.239

41. Jones, R.W. and Kierzkowski, H., 2001. A Framework for Fragmentation of Production. In: Arndt, S.W. and Kierzkowski, H., (Eds.). Fragmentation: New Production Patterns in the World Economy. Oxford: Oxford University Press.

42. Jucu, I., 2015. Romanian Post-Socialist Industrial Restructuring at the Local Scale: Evidence of Simulateneuous Processes of De-/ Reindustrialization in the Lugoj Municipality of Romania. Journal of Balkan and Near Eastern Studies, 17(4), pp.408-426. https:// doi.org/10.1080/19448953.2015.1063302.

43. Krugman, P.R., Cooper, R.N. and Srinivasan, T.N., 1995. Growing World Trade: Causes and Consequences. Brooking Papers on Economic Activity, 26(1), pp.327-377. https://doi. org/10.2307/2534577. 
Postelnicu, Dabija, Delocalization, Corporate Migration...

44. Labriandis, L. and Vogiatzis, N., 2011. Local Delocalization Across Borders: The Case of the Garment Quasi-Cluster in the Balkans. Journal of Borderlands Studies, 26(1), pp.35-51. https://doi.org/10 $.1080 / 08865655.2011 .590286$.

45. Leahy, D. and Montagna, C., 2000. Temporary Social Dumping, Union Legalisation and FDI: A Note on the Strategic Use of Standards. The Journal of International Trade \& Economic Development, 9(3), pp.243-259. https://doi.org/10.1080/09638190050086168.

46. Levchenko, A. and Zhang, J., 2014. Ricardian Productivity Differences and the Gains from Trade. European Economic Review, 65(C), pp. 45-65. https://doi.org/10.1016/j.euroecorev.2013.10.006.

47. Livesey, F., 1993. Dictionary of Economics. London: Pitman Publishing.

48. Lyberaki, A., 2011. Delocalization, Triangular Manufacturing, and Windows of Opportunity: Some Lessons from Greek Clothing Producers in a Fast-Changing Global Context. Regional Studies, 45(2), pp.205-218. https://doi.org/10.1080/00343400903380408.

49. Mazzanti, M., Montresor, S. and Pini, P., 2011. Outsourcing, Delocalization and Firm Organization: Transaction Costs versus Industrial Relations in a Local Production System of Emilia Romagna. Entrepreneuriship \& Regional Development, 23(7-8), pp.419-447. https://doi.org/10.1080/o8985620903233986.

50. McCollum, J.K. and Schoening, N.C., 2002. Romania: A Case Study in Delayed Privatization. International Journal of Public Administration, 25(9-10), pp.1221-1234. https://doi.org/10.1081/ pad-120006134.

51. MECRMA, 2016. Evoluția comerțului exterior. Buletin informativ lunar, 2, București: Ministerul Economiei, Comerțului și Relațiilor cu Mediul de Afaceri, viewed 21 April 2016: http://www.dce.gov.ro/ Materiale\%20site/Sinteza/sinteza_2016/feb.pdf.

52. Mirani, R., 2014. In Pursuit of Institutional Legitimation: Structuration of an Offshoring Decision. Journal of Information Technology Case and Application Research, 16(2), pp.70-90. https://doi.org/10.1080/15228053.2014.940259.

53. Negrescu, D., 2000. Un deceniu de privatizare în România. In: Ruehl, C. and Dăianu, D., (Eds.). Tranziția economică în România: trecut, prezent și viitor. București: Banca Mondială și Centrul Român pentru Politici Economice. 
54. Niță, M., 2008. Strategii și tehnici promoționale pentru creșterea producției în domeniul confecțiilor de îmbrăcăminte. București: Editura ASE.

55. OECD, 2007. Les delocalisations et l'employ. Tendencies et impact. Paris: OECD Publications.

56. Oke, A. and Onwuegbuzie, H., 2013. Outsourcing, subcontracting in and radical innovativeness. Journal of Manufacturing Technology Management, 24(4), pp.511-535. https://doi. org/10.1108/17410381311327387.

57. Pâslaru, S., 2011. Capitalismul nomad: Poate fi plecarea Nokia un semn că urmează a doua dezindustrializare a României? Ziarul Financiar, număr special, 02/10/2011, viewed 30 January 2015: http://www.zf.ro/special/capitalismul-nomad-poate-fi-plecareanokia-un-semn-ca-urmeaza-a-doua-dezindustrializare-a-romanieio-analiza-de-sorin-paslaru-8831709.

58. Pickles, J. and Smith, A., 2011. Delocalization and Persistence in the European Clothing Indutry: The Reconfiguration of Trade and Production Networks. Regional Studies, 45(2), pp.167-185. https:// doi.org/10.1080/00343401003601933.

59. Piergiorgio, V. and Rizzardi, R., 2014. Delocalization, Corporate Migration, and Transfer of Headquarters. Milan: IPSOA.

6o. Popescu, D.D. and Ciora, C., 2015. The Second Wave of Restructuring in Romania. AChange of Paradigm. Procedia Economics and Finance, 32, pp.1289-1304. https://doi.org/10.1016/s2212-5671(15)01506-3.

61. Postelnicu, G. and Postelnicu, C., 2000. Globalizarea economiei. București: Editura Economică.

62. Postelnicu, C., 2005. Fïrmele multinaţionale la început de mileniu. Cluj-Napoca: Risoprint.

63. Postelnicu, C. and Dabija, D.C., 2015. Transfer and Diffusion of New Technologies Within the Supply Chain of Multinational Companies with Operations in Romania - A Contemporary Approach. In: Văduva, S. and Thomas, A.R., (Eds.). Geopolitics, Development, and National Security. Romania and Moldova at the Crossroads, New York: Springer Briefs in Political Science, pp.53-66. https://doi. org/10.1007/978-3-319-12685-2_3.

64. Rowthorn, R. and Ramaswamy, R., 1997. Deindustrialization - Its Causes and Implications. International Monetary Fund, Economic Issues, 10, Washington, D.C., viewed 30 January 2015: https://www. imf.org/EXTERNAL/PUBS/FT/ISSUES1o/issue10.pdf. 
Postelnicu, Dabija, Delocalization, Corporate Migration...

65. Sass, M. and Fifekova, M., 2011. Offshoring and Outsourcing Business Services to Central and Eastern Europe: Some Empirical and Conceptual Consideration. European Planning Studies, 19(9), pp.1593-1609. https://doi.org/10.1080/o9654313.2011.586196.

66. Sava, D., 2003. Despre valoarea adăugată în țara lohn-ului. Ziarul Financiar, 27.10.2003, viewed 30 January 2015: http://www. zf.ro/afaceri-de-la-zero/despre-valoare-adaugata-in-tara-lohnului-2971127.

67. Sheldon, F., 1992. NAFTA as Social Dumping. Challenge, 35(5), pp.27-32. https://doi.org/10.1080/05775132.1992.11471613.

68. Telegdy, A., 2002. Privatizarea MEBO în România. Procesul de privatizare și rezultatele împroprietăririi. Universitatea de Ştiințe Economice Budapesta, Universitatea Central-Europeană Budapesta, European Federation of Employee Share Ownership, viewed 30 January 2015: http://www.efesonline.org/CEEEONet/ REPORTS\%2O2002/National\%20Report\%20Romania\%20RO.pdf.

69. Ternaux, P. and Kolarova, D., 2007. Delocalization and ICT Outsourcing in the CEEC Countries: The Role of Proximities. The Service Industries Journal, 27(3), pp.279-292. https://doi. org/10.1080/02642060701207122.

70. Thompson, G.R. and Valsan, C., 1999. Early Privatization in Romania. Eastern European Economics, 27(6), pp.35-53. https://doi.org/10.1 o80/00128775.1999.11648704.

71. Totev, S. and Sariiski, G., 2010. Industrial Delocalization in an Integrating Europe. Eastern European Economics, 48(1), pp.43-63. https://doi.org/10.2753/eeeo012-8775480103.

72. UNIDO, 2003. International Subcontracting Versus Delocalization. Geneva: UNIDO Report.

73. Valsan, C., 2001. Three Measures of Corporate Restructuring in a Transition Economy: The Case of Newly Privatised Romanian Companies. Post-Communist Economies, 13(1), pp.121-128. https:// doi.org/10.1080/14631370123632.

74. van der Zee, Ed., 2007. Delocalisation of EU Industry. Delocalisation and the Challenge of Structural Adjustment. A Review of Policy Options, Policy Department, Economic and Scientific Policy, European Techno-Economic Policy Support Network (ETEPS AISBL), Bruxelles: European Parliament.

75. Villemus, P., 2005. Delocalisation: Aurons-nous encore des emplois demain? Paris: Seuil. 
76. World Trade Organization, 2005. Offshoring: More Fears and Hopes than Facts, WTO World Report 2005.

77. Yeats, A.J., 2001. Just How Big is Global Production Sharing?, In: Arndt, S.W., Kierzkowski, H., (Eds.). Fragmentation: New Production Patterns in the World Economy. Oxford: Oxford University Press, pp.108-143.

78. Zhu, S. and Pickles, J., 2014. Bringing In, Go Up, Go West, Go Out: Upgrading, Regionalisation and Delocalisation in China's Apparel Production Networks. Journal of Contemporary Asia, 44(1), pp.3663. https://doi.org/10.1080/00472336.2013.801166. 